\title{
DEMOCRATIC VIRTUE, COMPARATIVE ETHICS, AND CONTEMPORARY ISLAM
}

\author{
John Kelsay
}

\begin{abstract}
This essay illustrates the kind of moral analysis Jeffrey Stout advocates in Democracy and Tradition by way of examining a conversation among Muslims that took place between June and December 2002. Their debate centers on al-Qaida's legitimacy as God's chosen defender of Islam, which is called into question due to the tension between al-Qaida's military tactics and the concepts of honorable combat held within the Islamic tradition. This giving and taking of reasons in both defense and detraction of al-Qaida's tactics demonstrates the living reality of Islamic tradition-the ongoing process of striving to discern God's will in light of communal agreements about the authority of certain texts and the validity of established rules for interpreting them.
\end{abstract}

KEY WORDS: Jeffrey Stout, Sharia reasoning, divine law governance, jihad, comparative religious ethics

\section{Introduction}

Scott Davis and Barney Twiss are interested in the philosophical or theoretical dimensions of Jeff Stout's work. I am interested in these as well. I think it will be more useful for me to present something different, however. And so I am going to focus on a description of moral argument among Muslims, specifically among fundamentalists or, as I prefer, "advocates of divine law governance in the strict sense." These include representatives of al-Qaida, and the discussion centers on al-Qaida's right to claim standing as the vanguard of Islam, chosen by God to secure the interests of the contemporary Muslim community.

In presenting these remarks, I propose that readers consider them an illustration of the kind of analysis Stout advocates. Stout (building on Brandom) suggests we attend to the forms of argument by which members of a community engage one another, giving and taking reasons, making claims and counterclaims regarding the validity of certain inferences. With respect to contemporary Muslims, these remarks track a "piece" of Sharia reasoning, in which Muslims engage in a transgenerational conversation about the "fit" between precedents established in approved texts and current circumstances. 
I do not have much space, and want to get down to describing four moments in a conversation among Muslims that took place between June and December 2002. I would like to suggest, though, that one of the virtues of Stout's approach is to remind us that comparison is nothing weird or strange. Comparison is an activity in which ordinary people engage every day. Correlatively, the comparative study of religious ethics does not need an elaborate theory, for example of the type intended to prove that comparison is possible. The comparative study of religious ethics is simply an academic form of the everyday phenomenon by which people compare and contrast styles of reasoning, forms of life, notions of the good, and so on. We are much in need of attention to the different ways people go about this, and of careful reflection on what makes for good, or useful comparisons. For example, we need to talk thoughtfully about the phenomenon of invidious comparison, which it seems is always with us. We need, as well, to talk about comparisons that flatten or reduce disagreement in the service of avoiding conflict. But we do not need theories that will make comparison possible. We need ways to talk about the purposes comparison serves.

For Stout, comparison is an aspect of democratic citizenship. One might even say it is a constitutive aspect of democratic virtue. It would be useful for Stout to elaborate on that notion. Among other things, it seems that this way of putting things would mean that Barney Twiss's suggestion, that Stout sees comparative ethics as a way of resolving conflict, is not quite right (Twiss 2005, 653). Indeed, it may be that comparative ethics is a way of engaging in healthy conflict. At the very least, one would not say, on my account of Stout's proposal, that comparison requires justification in terms of its contribution to conflict resolution. Instead, one would say that comparison, in the sense that involves listening carefully to others, interpreting them as reason-givers like oneself and one's near companions, arguing with them in the spirit of fellow seekers, and with the possibility of personal and social expansion, is characteristic of a "democratic individual."

\section{Contemporary Islam and the Sharia System ${ }^{1}$}

For now, I propose that we listen to Muslims. The heart of these remarks, as noted, is a depiction of four moments in a conversation among advocates of divine law governance in the strict sense. The subject is alQaida's claim to represent the Islamic tradition. As such, the argument is a debate about the Sharia, a term usually rendered as "divine law," but

\footnotetext{
${ }^{1}$ What follows is a very terse summation of material presented at greater length, and in other forms, in Kelsay 2003a, b, and c, as well as Kelsay 2002.
} 
more literally meaning "the path that leads to happiness" in this world and the next.

Arguments about the Sharia proceed on the basis of communal agreements, first, that certain texts establish precedents or "signs" with respect to the path. Second, such agreements set rules for the interpretation of the aforementioned texts. The purpose of argument is to "comprehend" divine guidance by establishing a fit between current circumstances and textual precedents. Historically, it must be said, argument pertaining to the Sharia was the preserve of specialists. Over the last 150 years, however, the Sharia reasoning has become a framework for public discourse, so that nonspecialists feel free to issue opinions and participate in the argument.

With respect to these remarks, the precedents at stake relate to (1) the duty to establish a just political order, and (2) notions of honorable combat. The first has been central to the Sharia argument since the demise of the Ottoman rulers in 1924. One side insists that justice requires an Islamic State, in the sense of a political regime dedicated (a) to the establishment of Islam as the state religion, and (b) to the implementation of divine law, in the sense that policies are clearly derived from textual precedents. The other side argues that God fills the earth, that wisdom is worthy of respect wherever one finds it, and thus that a just political order is one in which policies may be described as consistent with Islamic values. As indicated above, I classify the former as the position taken by "advocates of divine law in the strict sense"; I usually think of the latter as "pluralists."

The conversation I shall describe below involves the advocates of divine law governance in the strict sense. All of them agree that an Islamic State is required, and they further agree that this phrase indicates a political regime dedicated to propositions (a) and (b), as outlined above. They are concerned about al-Qaida's claim to status as the vanguard of Islam for the establishment of an Islamic State, however. In particular, they are concerned about al-Qaida's adherence to notions of honorable combat; if you will, to the Islamic analogue to the just war tradition. The Sharia reasoning on matters of fighting reveres the saying of the Prophet: "Do not cheat or commit treachery. Do not mutilate anyone, nor should you kill children" (Sahih Muslim, "Book of the Holy Struggle," report 1731). Herewith, then, is an account of arguments between the advocates of divine law governance with respect to al-Qaida's tactics.

June 7, 2002: An al-Qaìda spokesperson named Sulayman abu Ghayth publishes an article entitled "In the Shadow of the Lances" on the internet. ${ }^{2}$ Abu Ghayth (who had become well-known for several statements

${ }^{2}$ Abu Ghayth's article (Abu Ghayth, 2002) was originally published at www.alneda.com, which at the time was a frequent location for al-Qaida-related postings. The website 
following 9/11 and the beginning of U.S.-led action in Afghanistan) begins by indicating his purpose, to address the Muslim community and make sure it understands al-Qaìda's arguments:

Perhaps the Islamic community is waiting for one al-Qaida man to come out and clear up the many questions that accompany any communiqué, message, or picture [concerning 9/11], to know the truth, the motives, and the goals behind conflict with the Great Idol of our generation.

Abu Ghayth's article develops in accord with this purpose. It is a defense of al-Qaida's program of fighting against the United States and its allies. He lists a number of reasons that justify such fighting. For example:

America is the head of heresy in our modern world, and it leads an infidel democratic regime that is based upon separation of religion and state and on ruling the people by the people via legislating laws that contradict the way of God and permit that which God has prohibited. This compels the other countries to act in accordance with the same laws in the same ways... and punishes any country [that resists] by besieging it, and then by boycotting it. In so doing, [America] seeks to impose on the world a religion that is not God's.

The United States, then, is a prime example of an unjust state, since it is not governed by divine law. Its injustice is compounded by the fact that it seeks to export this form of government. And, as we come to understand, the injustice of the United States is expressed by its willingness to use or to support the use of military force against those who would choose another model for political order. Abu Ghayth lists various places in which this is so: Palestine, Iraq, Afghanistan, Somalia, Sudan, the Philippines, Indonesia, Kashmir, and others. In many of the cases, he cites a number indicating (as he takes it) the number of innocents killed. This is critical to the argument. For Abu Ghayth wants ultimately to justify not only armed resistance to the United States and its allies, but the kind of armed resistance advocated by the leaders of al-Qaida's and related groups in the 1998 Declaration on armed struggle against Jews and Crusaders. In that document, Usama bin Ladin and others argued that fighting against Americans and their allies, "civilians and soldiers" is a duty for each and every Muslim able to do so. In other words, al-Qaida's strategy involves deliberate attacks on civilian, as well as military targets. Abu Ghayth wants to provide a justification for this:

changes URLs frequently, however, so that it is difficult to locate. A convenient translation of portions of the article is available at the website of the Middle East Media Research Institute, http://www.memri.org, where it is entry No. 388 in the "Special Dispatch Series." I quote from MEMRI's translation, with very slight alterations. 
God said, "One who attacks you, attack as he attacked you," and also, "The reward of evil is a similar evil," and also "When you are punished, punish as you have been punished” [see Qur'an 2: 190a, 194].

These Qur'anic citations, as interpreted by recognized religious scholars, establish a right of reciprocal justice. According to this notion, victims of injustice have the right to inflict damage on those responsible for their suffering, in a manner proportionate to the harm suffered. According to this line of thought, the numbers of innocents killed by the United States suggests that:

We [Muslims] have not reached parity with them. We have the right to kill 4 million Americans, 2 million of them children, and to exile twice as many and wound and cripple hundreds of thousands.

It is important to note that Abu Ghayth stipulates that the damage inflicted by the United States and its allies is both "direct and indirect." For his purposes, the distinction does not matter. Those who suffer have the right to inflict damage proportionate to their losses. And this, he writes, is the only way to deal with the United States:

America knows only the language of force. This is the only way to stop it and make it take its hands off the Muslims and their affairs. America does not know the language of dialogue or the language of peaceful coexistence! America is kept at bay by blood alone.

Abu Ghayth's article provides an important defense of al-Qaìda tactics. Other Muslims are not persuaded, however. And thus I turn to a second moment in a recent conversation about Islam and fighting.

July 10, 2002: The television network al-Jazeera interviewed a wellknown Saudi religious scholar and dissident, Shaykh Muhsin al-Awaji. ${ }^{3}$ Two other dissidents joined by telephone. All three had served time in Saudi prisons for criticism of the royal family and its policies of cooperation with the United States during, and especially following Operations Desert Shield and Desert Storm in 1990-91. None of the three is friendly to the U.S. policies with respect to historically Muslim states. Indeed, they are in favor of armed resistance to the U.S. aggression, and approve the use of martyrdom operations.

The conversation then turns to Usama bin Ladin. Since the three scholars agree with al-Qaida on the necessity of governance by divine law, and further on the justice of resistance to the United States and its allies, it is most interesting that they indicate that, after initial approval

\footnotetext{
${ }^{3}$ Again, a convenient translation of portions of the transcript (Al-Awaji 2002) may be found at http://www.memri.org; Special Dispatch Series, entry number 400. Quotes are from the MEMRI translation.
} 
of bin Ladin, they and many others have changed their opinion. Shaykh al-Awaji says:

In the past, when he was fighting the Russians in Afghanistan, bin Ladin was the greatest of jihad warriors, in the eyes of the Saudi people and in the eyes of the Saudi government. He and the others went to Afghanistan with official support, and the support of the learned [the ulama or religious scholars].

In some ways, this positive assessment of bin Ladin still holds:

What the Saudis like best about bin Ladin is his asceticism. When the Saudi compares bin Ladin to any child of wealthy parents, he sees that bin Ladin left behind the pleasures of the hotels for the foxholes of jihad, while others compete among themselves for the wealth and palaces of this world.

Nevertheless, this positive judgment must now be qualified, because of al-Qaìda's tactics. Bin Ladin is guilty of spreading discord among Muslims. He labels people as heretics when he has no proof, and some alQaida's operations bring harm to Muslims. Bin Ladin and his colleagues also violate the Islamic norms of honorable combat, and this is an important reason for qualifying earlier, positive assessments:

$[\mathrm{H}] \mathrm{e}$ and those with him target innocent people, and I refer to the innocents on the face of the entire earth, of every religion and color, and in every region.

Recalling Islamic tradition on these matters, one cannot help but think of the saying of the Prophet: "Do not cheat or commit treachery. Do not mutilate anyone or kill children [or other noncombatants]." Shaykh alAwaji is far from approving of Abu Ghayth's (or al-Qaida's) notion of reciprocal justice. For him (and for those joining him on the show, since they indicate agreement with all of his points on this matter), Muslims are to fight with honor. This means, among other things, that they are not to engage in direct attacks on noncombatants.

We should not forget that Shaykh al-Awaji and his colleagues agree with much of al-Qaida's program. As I have said, they are not favorably disposed to U.S. policies in the Middle East and elsewhere. The point is that they want to see Muslims fight according to traditional norms.

September 2002: A different kind of criticism was articulated a few months later by Shaykh Umar Bakri Muhammad of al-Muhajiroun ("The Emigres"), a fundamentalist group based in the United Kingdom. Shaykh Umar's tract, Jihad: The Method for Khilafah? appeared at the group's website www.almuhajiroun.com (Muhammad 2002). ${ }^{4}$ While hardly an

\footnotetext{
${ }^{4}$ This site was accessed in late 2002, but it is currently inoperative.
} 
elegant piece of work, and thus difficult to read, this tract attempts to evaluate the place of armed struggle in the attempt to found a state governed by divine law. The author then discusses the nature and place of armed resistance in contemporary contexts.

According to Shaykh Umar, jihad, in the sense of "armed struggle," is a term reserved for fighting authorized by an established Islamic government. This is the sense of the reference to khilafah in his title. Literally, the term suggests "succession" to the Prophet Muhammad. Shaykh Umar uses the term as a designation for Islamic government. His discussion reiterates one of the great themes of Islamic political thought, that is, the necessity that justice be embodied in a political order. And, as he indicates, when this political order is in place, it should seek to extend its influence by appropriate means. These can and should include honorable combat.

For the last eighty years, the kind of authority indicated by the term khilafah has been absent from political life. This fact sets the context for the rest of Shaykh Umar's argument. Muslims are required to work to change this situation, and to establish khilafah. To that end, may or should they engage in jihad? The answer is no, first of all because of the nature of the concept. Jihad designates fighting that occurs under the auspices of an established government. By definition, then, fighting that takes place apart from such a government's authorization cannot be jihad. To this definitional "no" Shaykh Umar adds a second reason: Islamic political thought requires that authority be legitimate, in the sense of established through a process of consultation and assent. The submission of Muslims to an authority thus ought not be compelled. An Islamic government should be established through persuasion.

Shaykh Umar indicates that the process of consultation and assent may be conducted in a number of ways. He then moves to a discussion of contemporary resistance among Muslims. In his view, the Muslim community is in a kind of political twilight zone. Without a duly constituted khilafah, there can be no fighting worthy of the title jihad. Yet Muslims are in need of defense, in Chechnya, Kashmir, and other locations. What are they to do?

As Shaykh Umar has it, Islam recognizes a right of extended selfdefense. Everyone has the right to defend his/her own life, liberty, and property. Everyone also has the right, and in some sense the duty to defend the lives, liberties, and properties of others who are victims of aggression. This kind of fighting is called qital, a word that quite literally indicates "fighting" or "killing." Where Muslims are under attack, their coreligionists around the globe may and should come to their defense. When they do, however, they should understand that fighting is delimited, first in terms of its goals. Qital is not jihad. As such, it is not a proper means of establishing an Islamic government. Second, qital is limited in 
its means. Interestingly, in this qital and jihad are similar, since both are governed by norms of honorable combat, or as Shaykh Umar puts it, by the "pro-life" values of the Prophet Muhammad: "not killing women and children, not killing the elderly or monks, not targeting the trees or animals ... foreign forces occupying Muslim lands are legitimate targets and we are obliged to liberate Muslim land from such occupation and to co-operate with each other in the process, and can even target their embassies and military bases..." Tactics that involve direct attacks on noncombatants are ruled out, however.

Shaykh Umar's argument challenges al-Qaida's approach at a number of points. Most important for our purposes, however, is the stipulation that even defensive fighting, which almost by definition involves coming to the aid of Muslims in emergency or near emergency conditions, should be governed by norms of honorable combat. It's not surprising, given arguments like this, that the leadership of al-Qaida would respond.

November 2002: Usama bin Ladin, or someone writing in his name, published a "Letter to America" responding to Muslim and non-Muslim criticisms of al-Qaida. ${ }^{5}$ The first part of the "Letter" is a list of reasons for fighting against the United States and its allies. The grievances are familiar. On this point, the "Letter" restates and extends grievances outlined in earlier documents, not least Sulayman Abu Ghayth's internet article (above).

The second part of the text moves to the question of tactics:

You may then dispute that all the above does not justify aggression against civilians, for crimes they did not commit and offenses in which they did not partake.

The concern here is clearly with arguments that al-Qaida tactics violate norms of honorable combat. The author of "Letter" does not accept these. Two counterarguments are cited in justification of a policy of attacking civilians as well as soldiers. First, the United States claims to be a democracy:

Therefore, the American people are the ones who choose their government by way of their own free will; a choice which stems from their agreement to its policies... The American people have the ability and choice to refuse the policies of their government and even to change it if they want.

Second (and in a way reminiscent of Abu Ghayth's argument), the author cites the lex talionis:

\footnotetext{
${ }^{5}$ Translation available at http://observer.guardian.co.uk/worldview/story/0,11581, 845725,00.html. Quotes are from this source (Bin Laden 2002).
} 
God, the Almighty, legislated the permission and the option to take revenge. Thus, if we are attacked, then we have the right to attack back. Whoever has destroyed our villages and towns, then we have the right to destroy their villages and towns. Whoever has stolen our wealth, then we have the right to destroy their economy. And whoever has killed our civilians, then we have the right to kill theirs.

Harm suffered may be avenged by the infliction of damage proportionate to the original harm. Muslims have the right to kill U.S. and other "enemy" civilians, because the United States and its allies engage in actions that kill civilians on the Muslim side.

\section{Concluding Remarks}

What are we to make of this exchange? Primarily, I think it is important to know that such conversations take place. The post-September 11 discussion of Islam and fighting tends to swing between two assertions: Either Islam has nothing to do with fighting of this type, or Islam has everything to do with it. Neither of these assertions is accurate. Neither catches the sense of Islamic tradition as a living reality, in which human responsibility is construed as a process of discerning God's will in particular circumstances by reading agreed-upon texts and reasoning according to the established rules. To put it bluntly: In the Sharia vision, human responsibility is constituted by participation in an ordered process involving the giving and taking of reasons. In that light, it is important to get a sense of the conversations Muslims have about political justice and honorable combat.

Having said that, who won this argument? In one sense, that question must remain open-that is, in the sense that the argument is continuing. ${ }^{6}$ The tactics advocated by al-Qaida clearly raise important questions regarding the contemporary purchase of traditional notions of honorable combat. In another sense, however, the answer is clear enough. There is ample evidence of a gap between al-Qaida's jihad and the Islamic

\footnotetext{
${ }^{6}$ As I put the finishing touches on these remarks, an election in Iraq reiterates some of the most salient features of the argument. For example, Abu Musab al-Zarqawi's various statements reiterate themes presented by Sulayman Abu Ghayth and other representatives of al-Qaida, while opinions attributed to Abu Muhammad al-Maqdisi echo the views advanced by Al-Awaji and others: "The hands of the jihad fighters [i.e., those fighting against the U.S. and the Iraqi Provisional Authority, and who are opposed to elections] must remain clean so that they will not be stained by the blood of those who must not be harmed even if they are rebellious and shameless [e.g., by registering voters] ... You must beware of entanglement by choosing means of warfare that are illegal in Islamic law ..." (cf. http://www.memri.org, Special Dispatch 848—“Jordan/Jihad \& Terrorism Studies Project," January 17, 2005). Statements by Grand Ayatollah Sistani and others broaden the conversation further.
} 
tradition. The arguments between the advocates of divine law governance in contemporary Islam make it clear that advocating indiscriminate fighting, at least as a matter of settled policy, is a problematic course of action. What must be left open, or so I feel constrained to say at present, is whether there might be certain "emergencies" or extreme circumstances in which conscientious Muslims might argue that temporary or selected exceptions to the general norms of honorable combat might be justified, or at least that those carrying them out might be excused. This issue needs further analysis, not least by way of sustained attention to the rhetoric of al-Qaida and its Muslim critics.

There is of course much more to be said with respect to the contemporary Muslim argument related to al-Qaida. In these remarks, I have tried to display one set of arguments among certain groups of "allied" Muslims concerning al-Qaida's tactics. A more complete account would analyze arguments advanced by pluralists, as well as by these advocates of divine law governance in the strict sense. For now, I can conclude in this way: The post-9/11 Muslim discussion of al-Qaida tactics suggests the power of certain ideas; for example, that there are limits on what one can do, even when one is fighting for justice. In this sense, the post9/11 conversation among Muslims goes back to the Qur'an itself, which at 2:190 indicates to believers:

Fight against those who fight against you, but do not violate the limits!

God does not approve those who violate the limits.

I believe this is a notion in which all of us have an interest-Jews, Christians, Muslims, religious and nonreligious people alike. I offer the analysis in this context as a small example of the kind of listening and answering back, which I believe is consistent with the spirit of Democracy and Tradition.

\section{REFERENCES}

Abu Ghayth, Sulayman

2002 "In the Shadow of the Lances." MEMRI Special Dispatch Series, 388. At http://memri.org/bin/articles.cgi?Page=archives\&Area= sd\&ID=SP38802 (accessed December, 2002).

Al-Awaji, Shaykh Muhsin

2002 Interview with Al-Jazeera. "Saudi Opposition Sheikhs on America, Bin Laden, and Jihad." MEMRI Special Dispatch Series, 400. At http://memri.org/bin/articles.cgi?Page=archives\&Area $=$ sd\&ID= SP40002 (accessed December, 2002).

Bin Ladin, Usama

2002 "Letter to America." At http://observer.guardian.co.uk/worldview/ story/0,11581,845725,00.html (accessed December, 2002). 
Kelsay, John

2002 "Bin Laden's Reasons: Interpreting Islamic Tradition.” The Christian Century 119/5 (February 21-March 6): 26-29.

2003a "Islam, Politics, and War." Sewannee Theological Review 47/1: 1119.

2003b "War, Peace, and the Imperatives of Justice: What Do the 11 September 2001 Attacks Tell Us About Islam and the Just War Tradition?" In Just War in Comparative Perspective, ed. Paul Robinson. Hampshire, England, and Burlington, VT: Ashgate, pp. 76-89.

2003c "The New Jihad and Islamic Tradition.” Foreign Policy Research Institute WIRE 11/3 (October). At http://www.fpri.org.

Muhammad, Shaykh Umar Bakri

2002 Jihad: The Method for Khilafah? At http://www.almuhajiroun.com (accessed December, 2002).

Sahih Muslim

1999 Sahih Muslim 8 vols. Translated by 'Abdul Hamid Siddiqi. Delhi, India: Adam Publishers and Distributors.

Stout, Jeffrey

2004 Democracy and Tradition. Princeton: Princeton University Press.

Twiss, Sumner B.

2005 "Comparative Ethics, a Common Morality, and Human Rights." Journal of Religious Ethics 33.4 (December): 649-57. 